\title{
THE IMPACT OF ANTHROPOPRESSURE ON PHYSICOCHEMICAL STATE OF THE KORZKIEWKA STREAM
}

\author{
Agnieszka Policht-Latawiec ${ }^{1}$, Włodzimierz Kanownik ${ }^{1}$ \\ 1 Department of Land Reclamation and Environmental Development, University of Agriculture in Krakow, \\ Mickiewicza Av. 24-28, 30-059 Krakow, Poland, e-mail: a.policht@ur.krakow.pl; rmkanown@cyf-kr.edu.pl
}

Received: 2017.05.26

Accepted: 2017.08.01

Published: 2017.09.01

\begin{abstract}
The aim of the paper was the identification and assessment of the area of anthropogenic impacts on water quality in the catchment of the Korzkiewka stream flowing through the areas of the Malopolska region. Analyses of physicochemical indices revealed that waters along the whole length of the stream qualified for below good status due to the exceeded EC and nitrate nitrogen concentrations. It was found that among 21 analyzed physicochemical indices, statistically significant differences occurred for 5: total dissolved solids, $\mathrm{SO}_{4}{ }^{2-}, \mathrm{Mg}^{2+}, \mathrm{K}^{+}$and water $\mathrm{pH}$. In the headwaters section values of four salinity indices were significantly higher in relation to the other part of the stream. Assessment of anthropogenic factors affecting the catchment water resources conducted on the basis of unitary and percent indices revealed that the dominant category shaping the physicochemical status of the Korzkiewka stream water is municipal economy. The intensity of the influence of the factors from this category was from medium to very high, while in case of sewage discharged through the sewage network, even to outlier intensity. Forestry and agriculture exerted medium pressure, whereas the factors from the industry category had hardly any influence on water in the stream.
\end{abstract}

Keywords: water quality, anthropogenic factors, physicochemical indices, Korzkiewka stream

\section{INTRODUCTION}

Disposable resources of surface waters in Poland are among the smallest in Europe. They are characterized by a considerable variability in time and space [Kanownik and Kowalik 2010] and low quality, therefore, small possibility of its use [Kanownik et al. 2013, Policht-Latawiec and Kanownik 2015]. Guided by rational premises, we should implement programmes of proper management and protection of water resources according to the principle of sustainable development. Aiming at better protection of waters, in 2000 European Parliament and the Council adopted a directive establishing the framework of the common activities in the area of water policy based on clear, effective and coherent legislative actions. One of the priorities in this area is pre- venting further worsening, as well as protection and improvement of the status of aquatic ecosystems and wetlands directly dependent on aquatic ecosystems, as well as striving at a better protection and improvement of aquatic environment through gradual reduction of discharges, emission and losses of priority dangerous substances [Directive 2000].

Surface waters may be polluted by substances originating from anthropogenic sources [Húska et al. 2013, Kowalik et al. 2014] and due to natural processes occurring in the environment [Policht-Latawiec et al. 2014, Sojka et al. 2016]. The natural sources may include various kinds of pollutants, such as plant residue and humic substances, clayey and silt particles of soils or rocks, compounds of iron and manganese, etc. However, pollutants generated by human economic activi- 
ties are usually far more dangerous for the environment [Policht-Latawiec and Kanownik 2015, Dąbrowska et al. 2016].

Farming activities conducted by humans affect the quality of water resources, among others due to improper use of mineral and organic fertilizers and plant protection chemicals. Supplied to the soil, they may spread uncontrollably leading to decreasing the natural environment values. Substances worsening the condition of surface and ground waters penetrate to them with the runoffs from agricultural catchments. These are primarily nutrient compounds (nitrogen and phosphorus compounds), which at high concentrations are greatly unfavourable for the aquatic environment. They not only cause worsening of water quality and its unsuitability for drinking, but also water eutrophication and die-off of some plant and animal species, leading to the destruction of ecosystems. The speed of pollutant movement and their amount depend on numerous factors. Their migration and deposition are affected by the degree of civilizational development, soil, geological and climate conditions in a given region, as well as intensity and the way of agricultural land use [Marks-Bielska 2011, Kanownik et al. 2013, Mazur 2013, Pytka et al. 2013, Kowalik et al. 2014].

Assessment of water resources quality should be conducted on two levels. The most important is elimination of area pollutions at their sources, i.e. sanitation of rural areas, appropriate farming and application of proper agrotechnical measures, correct storage of liquid and solid natural fertilizers. Other methods of preventing aquatic environment degradation involve slowing down water and matter circulation in the catchment, limiting pollution spreading through the application of planning, technical and agrotechnical methods [Jóźwiakowski et.al. 2006, Sojka et al. 2008, Mioduszewski 2015].

The aim of the paper was identification and assessment of the impact of the area of anthropogenic factors on water quality in the Korzkiewka stream flowing through the areas of the Malopolska region.

\section{MATERIAL AND METHODS}

Hydrochemical analyses of the Korzkiewka stream were conducted in 2014. The stream is $4.93 \mathrm{~km}$ long with an average channel slope $1.8 \%$. Due to karst character of the bedrock, the stream constant sources are located at $1 / 3$ of the catchment length in Brozówka Korzkiewska village at the altitude of about $348 \mathrm{~m}$ a.s.l. It flows in a narrow channel to the north towards Przybysławice village, where at the altitude of $258 \mathrm{~m}$ a.s.1 it flows into the Prądnik (Białucha) river. The watercourse with a rapid current, flows in an indented channel with a rocky substratum, stone-gravel in the lower course and according to the surface water typology is an upland carbonate stream with coarse-grained substrate (7). The stream catchment, with the area of $16.20 \mathrm{~km}^{2}$ is almost $9 \mathrm{~km}$ long. It is situated in the Malopolska province, Krakow county and in the area of Skała and Zielonki districts. According to the geographical division, the catchment is situated on the Krakow-Częstochowa Upland in the Olkusz Upland mezoregion. The catchment matrix consists of compact limestone slabs of the Upper Jura, which are divided into rocky, slab and bedded limestones. Their building material are siliceous sponges and mineralized rock deposits formed by microorganisms [Policht-Latawiec et al. 2015].

Water for analyses was sampled every month in 5 measurement-control points: point 1 at $\mathrm{km}$ $4+900$ of the watercourse, point $2-$ at $\mathrm{km} 2+360$, point 2 at $\mathrm{km} 1+500$, point $4-$ at $0+960$ and point 5 at $\mathrm{km} 0+020$ (Figure 1). The upper part of the catchment is almost wholly used for farming. Forest enclaves, meadows and pastures are located along the stream. Built-up and urbanized areas are situated primarily in the central part and constitute $2.6 \%$ of the catchment area.

In each control-measurement point on site, water $\mathrm{pH}$ was determined using $\mathrm{CP}-104 \mathrm{pH}$ meter, the temperature $(\mathrm{T})$ and electrolytic conductivity (EC) were measured using CC-103 conductometer, dissolved oxygen (DO) content and degree of water saturation with oxygen (OSD) were measured by CO-411 oxygen meter and total dissolved solids (TDS) by means of TDS meter (HACH LANGE).

The following assessments were conducted in the laboratory by means of referential methods [Regulation ME 2016a]: total suspended solids (TSS) by drying and weighing, concentrations of $\mathrm{Ca}^{2+}, \mathrm{Mg}^{2+}, \mathrm{Na}^{+}, \mathrm{K}^{+}, \mathrm{Fe}\left(\mathrm{Fe}^{2+}\right.$ and $\left.\mathrm{Fe}^{3+}\right)$ and $\mathrm{Mn}^{2+}$ ions by atomic absorption spectrometry (AAS) on UNICAM SOLAR 969 spectrometer. Fide-day oxygen demand $\left(\mathrm{BOD}_{5}\right)$ was assessed by Winkler's method, while chemical oxygen demand (COD-Mn) by titration in $\mathrm{KMnO}_{4}$. Concentrations of ammonium $\left(\mathrm{N}-\mathrm{NH}_{4}^{+}\right)$, nitrite $\left(\mathrm{N}-\mathrm{NO}_{2}^{-}\right)$ 


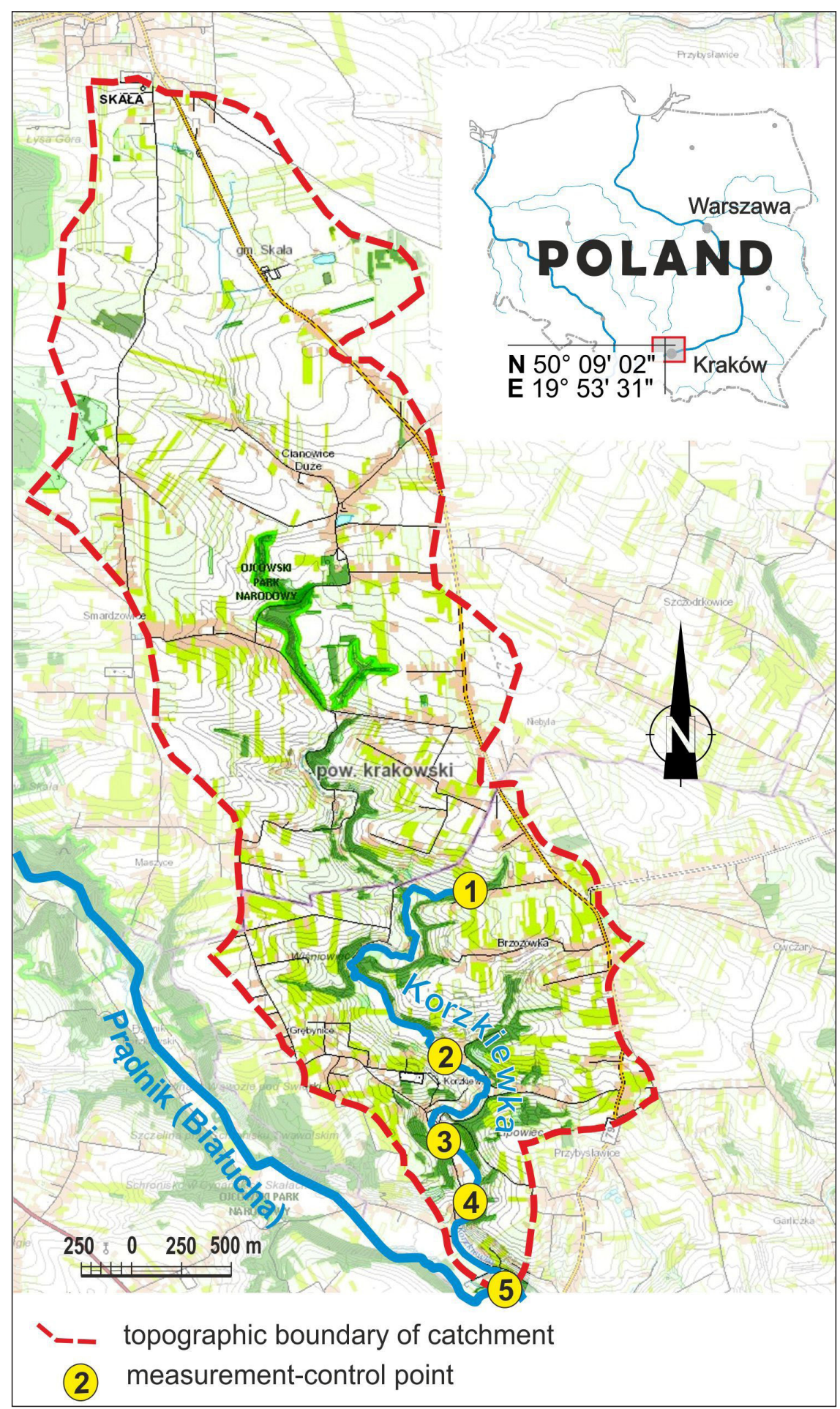

Figure 1. Location of measurement-control points in the Korzkiewka stream

and nitrate $\left(\mathrm{N}-\mathrm{NO}_{3}{ }^{-}\right)$nitrogen, as well as phosphate phosphorus $\left(\mathrm{P}-\mathrm{PO}_{4}^{3-}\right)$ and chlorides $\left(\mathrm{Cl}^{-}\right)$ were determined using flow colorimetry on FIAstar 5000 apparatus and sulphates $\left(\mathrm{SO}_{4}^{2-}\right)$ were assessed by precipitation method.

Elaboration of the results involved computing arithmetic mean values for individual water quality indices for the assessment of physicochemical status of the upland Korzkiewka stream, according to the Regulation of the Minister of Environment of 21 July 2016 [Regulation ME 2016b]. Statistical inference about the significance of differences of the indices values between the measurement-control points was conducted using Kruskal-Wallis non-parametric test. On the basis of multiple comparisons of mean ranges, it was 
checked which indices differed statistically significantly. The non-parametric tests were selected because of the lack of normality of distribution for most analyzed indices, according to the results of Shapiro-Wilk test and lack of equality of variance determined by Fisher-Snedecor test. Cluster analysis was conducted in the paper by grouping the objects (points) and features (physicochemical indices) [Stanisz 2007].

Identification and assessment of the causative agents influencing water resources in the catchment was done on the basis of unitary and percent indices developed by Nachlik [2004]. According to the method, the indices were compiled into three categories: municipal economy - 10 indices, agriculture and forestry - 11 indices, industry -10 indices. For each index threshold values were determined making possible the assessment of districts impact on water resources of the uniform water parts. 5 impact intensity classes were identified ( 1 - very low, 2 - low, 3 - medium, 4 - high, 5 - very high) so that the classes covered, respectively 10,20, 40, 20 and $10 \%$ of districts in Poland. Moreover, also class 0 was identified in the intensity assessment, meaning a lack of pressure and class 6 - outlier [Nachlik 2004, Smoroń and Kowalczyk 2014]. Because of a small area of the Korzkiewka stream catchment, unitary and percent indices of anthropopressure describe the conditions in this area or in Skała or Zielonki districts. In order to facilitate the interpretation and comparison of the catchment impact on water resources of the uniform water parts, the results were presented as radar charts.

\section{RESULTS AND DISCUSSION}

Average water temperature in the Korzkiewka stream during the period of investigations fluctuated from 9.7 to $11.7^{\circ} \mathrm{C}$ and reaction from neutral (pH 7.8) to alkaline ( $\mathrm{pH}$ 8.3). Total suspended solids content in water was low, on average from 1.7 to $4.7 \mathrm{mg} \cdot \mathrm{dm}^{-3}$, on the level of class I [Regulation ME 2016b]. Over the whole studied period water in the stream revealed very good oxygen conditions - average degree of saturation was over $90 \%$ and did not exceed $100 \%$, whereas average concentration of dissolved oxygen was over $9.5 \mathrm{mg} \cdot \mathrm{dm}^{-3}$. Values of $\mathrm{BOD}_{5}$ and COD-Mn were below the limit value for class I. Mean water electrolytic conductivity in all points exceeded the limit value $\left(506 \mu \mathrm{S} \cdot \mathrm{cm}^{-1}\right)$ for class II deter- mined for the abiotic 7 type in the Minister of Environment Regulation of 2016. Mean concentrations of dissolved solids ranged between 271 $\mathrm{mg} \cdot \mathrm{dm}^{-3}$ at the stream mouth to 352 in the headwaters area (Table 1). These were higher than the limit values for quality class I, which evidences the presence of mineral compounds in water. The highest mean sulphate $\left(\mathrm{SO}_{4}^{2-}\right)$ concentration was $72 \mathrm{mg} \cdot \mathrm{dm}^{-3}$. Mean chloride $\left(\mathrm{Cl}^{-}\right)$concentrations in the upper (point 1) and lower (points 4 and 5) parts of the stream were above $31.9 \mathrm{mg} \cdot \mathrm{dm}^{-3}$, which caused that the water did not meet the requirements for class II. In the middle part (points 2 and 3) mean chloride concentration was 29 $\mathrm{mg} \cdot \mathrm{dm}^{-3}$. Mean concentrations of $\mathrm{Ca}^{2+}$ and $\mathrm{Mg}^{2+}$ remained on similar level, except the upper reach of the steam, where mean value was exceeded, respectively by: 86.2 (class I) and $11.7 \mathrm{mg} \cdot \mathrm{dm}^{-3}$ (class II). It was observed along the whole length of the watercourse that mean concentrations of ammonium nitrogen and phosphate phosphorus (except point 4) exceeded the limit value for quality class I. Considering nitrite nitrogen concentrations, mean values in the upper part of the stream were on the level of class I. In points 3, 4 and 5 mean concentrations of nitrite nitrogen was $0.012 \mathrm{mg} \cdot \mathrm{dm}^{-3}$ (class II). In all analyzed points water revealed very high concentrations of nitrate nitrogen over the whole period of investigations. Mean concentration exceeded the limit value (2.7 $\mathrm{mg} \mathrm{N}-\mathrm{NO}_{3} \cdot \cdot \mathrm{dm}^{-3}$ ) for quality class II. The highest mean concentration of total iron $\left(0.17 \mathrm{mg} \cdot \mathrm{dm}^{-3}\right)$ was noted in point 2 , whereas the lowest $(0.12$ $\left.\mathrm{mg} \cdot \mathrm{dm}^{-3}\right)$ in point 1 . Manganese $\left(\mathrm{Mn}^{2+}\right)$ concentrations fluctuated on average from 0.04 to 0.10 $\mathrm{mg} \cdot \mathrm{dm}^{-3}$ (Table1).

Kruskal-Wallis non-parametric test revealed that statistically significant differences occurred for total dissolved solids, sulphates, manganese, potassium and water $\mathrm{pH}$, where the test probability was lower than 0.05 (Table 2). In case of $\mathrm{TDS}, \mathrm{SO}_{4}^{2-}, \mathrm{Mg}^{2+}$ and $\mathrm{K}^{+}$statistically significantly higher values occurred in the headwaters section of the stream. Water $\mathrm{pH}$ differed significantly between point 2 and points 4 and 5. The other analyzed indices differed with their values between individual points but the differences were statistically insignificant.

The conducted cluster analysis allowed to group the measurement-control points and analyzed physicochemical indices into clusters (Figure 2). A good example of grouping are values of the indices: $\mathrm{N}_{-} \mathrm{NO}_{3}^{-}, \mathrm{Cl}-\mathrm{SO}_{4}^{2-}, \mathrm{Mg}^{2+}, \mathrm{K}^{+}, \mathrm{Ca}^{2+}$, 
Table 1. Average values of physico-chemical elements and water quality class in the Korzkiewka stream

\begin{tabular}{|c|c|c|c|c|c|c|c|}
\hline \multirow{3}{*}{ Indices } & \multicolumn{5}{|c|}{ Average } & \multirow{2}{*}{\multicolumn{2}{|c|}{$\begin{array}{c}\text { Limit values } \\
\text { for class } \\
\text { [Rozporządzenie } \\
\text { MŚ 2016b] }\end{array}$}} \\
\hline & \multicolumn{5}{|c|}{ Measurement-control point } & & \\
\hline & 1 & 2 & 3 & 4 & 5 & 1 & II \\
\hline Temperature, ${ }^{\circ} \mathrm{C}$ & 9.7 & 10.3 & 10.5 & 10.7 & 11.0 & $\leq 22$ & $\leq 24$ \\
\hline $\begin{array}{l}\text { Total Suspended Solids } \\
\text { (TSS), } \mathrm{mg} \cdot \mathrm{dm}^{-3}\end{array}$ & 1.7 & 1.7 & 2.7 & 2.8 & 4.7 & $\leq 10.0$ & $\leq 19.8$ \\
\hline $\begin{array}{l}\text { Dissolved Oxygen } \\
\text { (DO), } \mathrm{mgO}_{2} \cdot \mathrm{dm}^{-3}\end{array}$ & 10.6 & 9.6 & 10.3 & 10.0 & 10.0 & $\geq 9.5$ & $\geq 7.5$ \\
\hline Oxygen Saturation Degree (OSD), \% & 96 & 91 & 96 & 94 & 96 & & \\
\hline $\begin{array}{l}\text { Biochemical Oxygen Demand } \\
\left(\mathrm{BOD}_{5}\right), \mathrm{mgO}_{2} \cdot \mathrm{dm}^{-3}\end{array}$ & 1.1 & 1.1 & 0.9 & 1.1 & 1.3 & $\leq 2.2$ & $\leq 3.7$ \\
\hline $\begin{array}{l}\text { Chemical Oxygen Demand (COD- } \\
\mathrm{Mn}), \mathrm{mgO}_{2} \cdot \mathrm{dm}^{-3}\end{array}$ & 1.8 & 1.7 & 1.9 & 2.2 & 2.2 & $\leq 5.5$ & $\leq 9.1$ \\
\hline $\begin{array}{l}\text { Electrolytic Conductivity } \\
(\mathrm{EC}), \mu \mathrm{S} \cdot \mathrm{cm}^{-1}\end{array}$ & 612 & 564 & 535 & 600 & 541 & $\leq 310$ & $\leq 506$ \\
\hline $\begin{array}{l}\text { Total Dissolved Solids } \\
\text { (TDS), } \mathrm{mg} \cdot \mathrm{dm}^{-3}\end{array}$ & 353 & 290 & 299 & 294 & 271 & $\leq 206$ & $\leq 370$ \\
\hline $\mathrm{SO}_{4}^{2-}, \mathrm{mg} \cdot \mathrm{dm}^{-3}$ & 72 & 35 & 34 & 36 & 35 & $\leq 28.5$ & $\leq 89.4$ \\
\hline $\mathrm{Cl}, \mathrm{mg} \cdot \mathrm{dm}^{-3}$ & 42 & 29 & 29 & 33 & 34 & $\leq 6.6$ & $\leq 31.9$ \\
\hline $\mathrm{Ca}^{2+}, \mathrm{mg} \cdot \mathrm{dm}^{-3}$ & 92 & 74 & 75 & 75 & 72 & $\leq 86.2$ & $\leq 96.7$ \\
\hline $\mathrm{Mg}^{2+}, \mathrm{mg} \cdot \mathrm{dm}^{-3}$ & 17.4 & 8.2 & 9.0 & 9.0 & 9.1 & $\leq 5.3$ & $\leq 11.7$ \\
\hline $\mathrm{Na}^{+}, \mathrm{mg} \cdot \mathrm{dm}^{-3}$ & 6.5 & 6.5 & 6.6 & 6.6 & 6.6 & & \\
\hline $\mathrm{K}^{+}, \mathrm{mg} \cdot \mathrm{dm}^{-3}$ & 3.0 & 2.0 & 1.9 & 2.0 & 1.9 & & \\
\hline Reaction, $(\mathrm{pH})$ & 8.1 & 7.8 & 8.0 & 8.2 & 8.3 & $7.6-8.3$ & $7.5-8.3$ \\
\hline 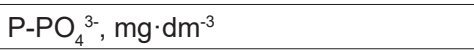 & 0.057 & 0.081 & 0.063 & 0.037 & 0.041 & $\leq 0.039$ & $\leq 0.101$ \\
\hline $\mathrm{N}-\mathrm{NH}_{4}{ }^{+}, \mathrm{mg} \cdot \mathrm{dm}^{-3}$ & 0.117 & 0.183 & 0.179 & 0.163 & 0.204 & $\leq 0.101$ & $\leq 0.822$ \\
\hline $\mathrm{N}-\mathrm{NO}_{2} \cdot, \mathrm{mg} \cdot \mathrm{dm}^{-3}$ & 0.006 & 0.008 & 0.012 & 0.012 & 0.012 & $\leq 0.01$ & $\leq 0.03$ \\
\hline $\mathrm{N}-\mathrm{NO}_{3}^{-}, \mathrm{mg} \cdot \mathrm{dm}^{-3}$ & 7.1 & 5.2 & 5.1 & 5.1 & 5.3 & $\leq 1.17$ & $\leq 2.7$ \\
\hline $\mathrm{Fe}, \mathrm{mg} \cdot \mathrm{dm}^{-3}$ & 0.12 & 0.17 & 0.13 & 0.15 & 0.16 & & \\
\hline $\mathrm{Mn}^{2+}, \mathrm{mg} \cdot \mathrm{dm}^{-3}$ & 0.10 & 0.09 & 0.05 & 0.05 & 0.04 & & \\
\hline
\end{tabular}

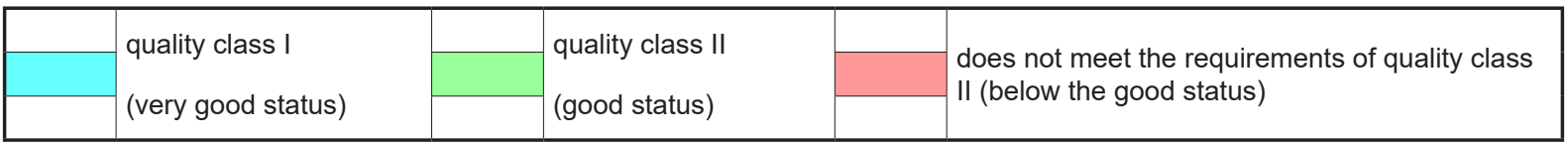

TDS, which allow to identify points $2,3,4$ and 5 as a single cluster with similar physicochemical features and point 1 (the headwaters part) considerably different from the others. The next group is formed of points 4 and 5 located in the lower part of the stream which stand out by higher values of water temperature, $\mathrm{pH}$, total suspended solid concentration, ammonium nitrogen and chemical (COD-Mn) and biochemical $\left(\mathrm{BOD}_{5}\right)$ oxygen demand.

The analysis of anthropopressure on water resources in the Korzkiewka stream was conducted in three categories (Figure 3): municipal economy (GK), agriculture and forestry (RL) and industry $(\mathrm{P})$.
Population density in the studied catchment area is 415 persons $\cdot \mathrm{km}^{-2}$ (Table 3 ), in comparison to population density in the Malopolska province ( 218 persons $\cdot \mathrm{km}^{-2}$ ) and in relation to the Krakow county (217 persons $\left.\mathrm{km}^{-2}\right)$. Technical infrastructure in the district has been developing successively. In 2010 population using sewage network constituted $48.1 \%$ and in the next year almost $72.5 \%$ of the district inhabitants. In 2011 water supply network served $84.6 \%$ of the inhabitants. The sewage network to water supply network ratio is 1.0 , because the length of the sewage network is $156 \mathrm{~km}$, whereas water supply system $157 \mathrm{~km}$ [Environmental 2012]. Water consumption for the water supply network is $0.54 \mathrm{dm}^{3} \cdot \mathrm{s}^{-1} \cdot \mathrm{km}^{-2}-$ a high 
Table 2. Comparison of quality indices values between the measurement and control points using Kruskal-Wallis nonparametric test

\begin{tabular}{|c|c|c|c|c|c|c|c|}
\hline \multirow{3}{*}{ Indices } & \multicolumn{5}{|c|}{ Measurement-control point } & \multicolumn{2}{|c|}{ Results of Kruskal-Wallis test } \\
\hline & 1 & 2 & 3 & 4 & 5 & \multirow{2}{*}{ Test value } & \multirow{2}{*}{ Test probability $(p)$} \\
\hline & \multicolumn{5}{|c|}{ Median } & & \\
\hline Temperature, ${ }^{\circ} \mathrm{C}$ & 9.4 & 10.1 & 10.2 & 10.4 & 10.5 & 1.1 & 0.90 \\
\hline Total suspended solids, $\mathrm{mg} \cdot \mathrm{dm}^{-3}$ & 2.0 & 1.0 & 1.5 & 2.5 & 3.0 & 5.03 & 0.28 \\
\hline Dissolved oxygen, $\mathrm{mg} \cdot \mathrm{dm}^{-3}$ & 10.8 & 9.6 & 10.3 & 9.9 & 10 & 6.8 & 0.15 \\
\hline Oxygen saturation degree, $\%$ & 96 & 92 & 96 & 95 & 97 & 3.3 & 0.50 \\
\hline $\mathrm{BOD}_{5}, \mathrm{mg} \mathrm{O}_{2} \times \mathrm{dm}^{-3}$ & 1.0 & 1.0 & 0.9 & 1.2 & 1.2 & 3.5 & 0.48 \\
\hline COD-Mn, $\mathrm{mg} \mathrm{O}_{2} \times \mathrm{dm}^{-3}$ & 1.7 & 1.7 & 1.9 & 2.3 & 2.2 & 7.1 & 0.13 \\
\hline Electrolytic conductivity, $\mu \mathrm{S} \cdot \mathrm{c}^{\mathrm{m}-1}$ & 612 & 607 & 613 & 613 & 537 & 5.3 & 0.26 \\
\hline Total dissolved solids, $\mathrm{mg} \cdot \mathrm{dm}^{-3}$ & $359^{2,3,4,5}$ & $291^{1}$ & $300^{1}$ & $299^{1}$ & $282^{1}$ & 18.9 & $<0.001$ \\
\hline $\mathrm{SO}_{4}^{2-}, \mathrm{mg} \cdot \mathrm{dm}^{-3}$ & $79^{2,3,4,5}$ & $34^{1}$ & $37^{1}$ & $40^{1}$ & $38^{1}$ & 13.8 & 0.008 \\
\hline $\mathrm{Cl}^{-}, \mathrm{mg} \cdot \mathrm{dm}^{-3}$ & 43 & 19 & 19 & 19 & 19 & 6.3 & 0.18 \\
\hline $\mathrm{Ca}^{2+}, \mathrm{mg} \cdot \mathrm{dm}^{-3}$ & 88 & 72 & 72 & 72 & 68 & 6.3 & 0.18 \\
\hline $\mathrm{Mg}^{2+}, \mathrm{mg} \cdot \mathrm{dm}^{-3}$ & $17.0^{2,3,4,5}$ & $8.1^{1}$ & $8.9^{1}$ & $8.9^{1}$ & $8.9^{1}$ & 16.7 & 0.002 \\
\hline $\mathrm{Na}^{+}, \mathrm{mg} \cdot \mathrm{dm}^{-3}$ & 6.6 & 6.5 & 6.6 & 6.6 & 6.6 & 1.1 & 0.90 \\
\hline $\mathrm{K}^{+}, \mathrm{mg} \cdot \mathrm{dm}^{-3}$ & $2.8^{2,3,4,5}$ & $1.8^{1}$ & $1.8^{1}$ & $1.9^{1}$ & $1.9^{1}$ & 15.7 & 0.003 \\
\hline Reaction, $(\mathrm{pH})$ & 8.1 & $7.8^{4,5}$ & 8.0 & $8.1^{2}$ & $8.3^{2}$ & 18.5 & 0.001 \\
\hline $\mathrm{P}-\mathrm{PO}_{4}{ }^{3-}, \mathrm{mg} \cdot \mathrm{dm}^{-3}$ & 0.055 & 0.059 & 0.055 & 0.038 & 0.052 & 4.1 & 0.39 \\
\hline $\mathrm{N}-\mathrm{NH}_{4}{ }^{+}, \mathrm{mg} \cdot \mathrm{dm}^{-3}$ & 0.070 & 0.068 & 0.058 & 0.080 & 0.070 & 0.46 & 0.98 \\
\hline $\mathrm{N}-\mathrm{NO}_{2}^{-}, \mathrm{mg} \cdot \mathrm{dm}^{-3}$ & 0.005 & 0.008 & 0.010 & 0.010 & 0.010 & 7.3 & 0.12 \\
\hline $\mathrm{N}-\mathrm{NO}_{3}^{-}, \mathrm{mg} \cdot \mathrm{dm}^{-3}$ & 7.6 & 5.5 & 5.3 & 5.2 & 5.4 & 7.6 & 0.11 \\
\hline $\mathrm{Fe}, \mathrm{mg} \cdot \mathrm{dm}^{-3}$ & 0.12 & 0.14 & 0.15 & 0.18 & 0.11 & 1.0 & 0.91 \\
\hline $\mathrm{Mn}^{2+}, \mathrm{mg} \cdot \mathrm{dm}^{-3}$ & 0.04 & 0.05 & 0.03 & 0.04 & 0.04 & 2.9 & 0.58 \\
\hline
\end{tabular}

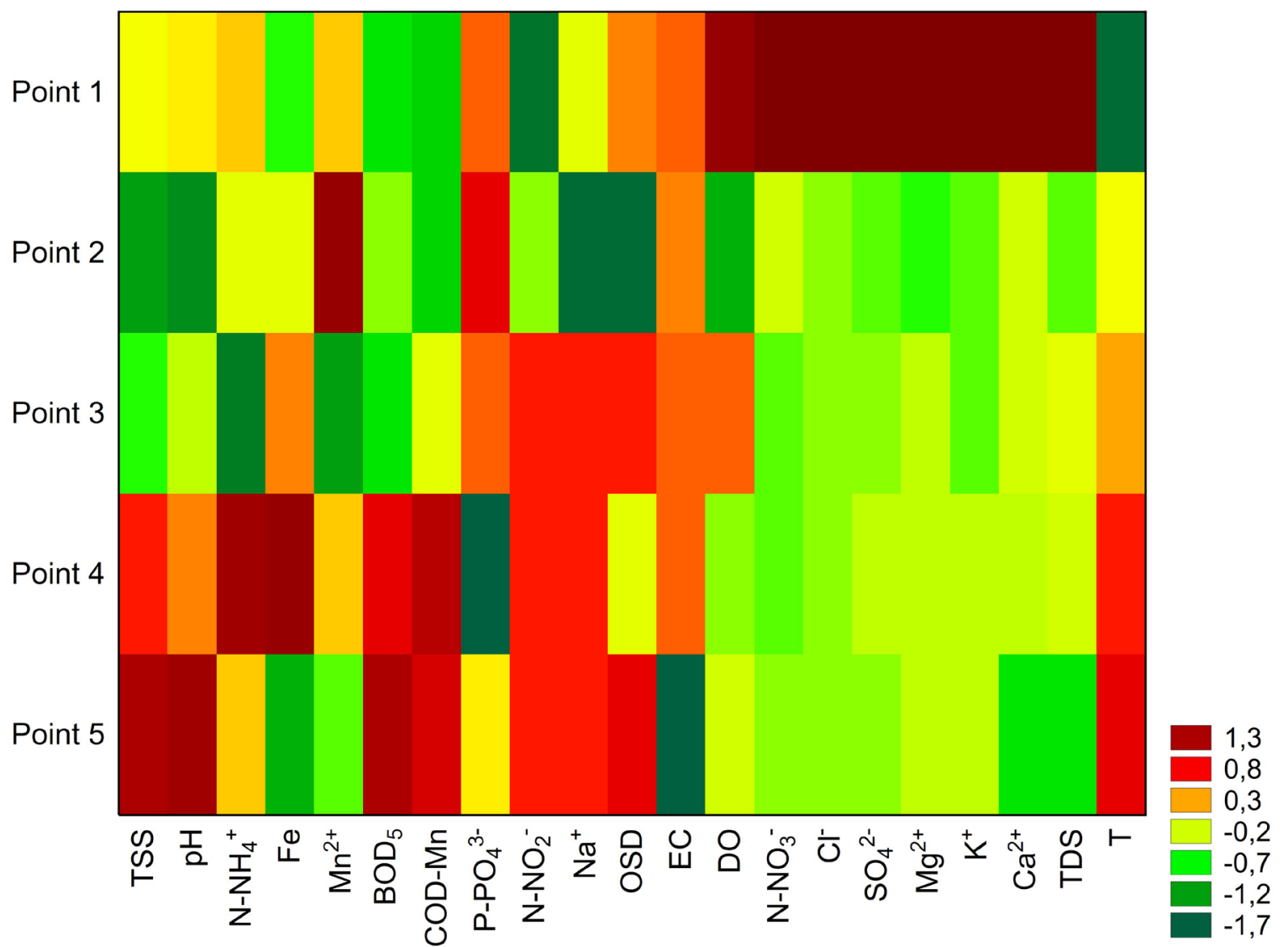

Figure 2. Results of grouping measurement-control points and physicochemical indices 

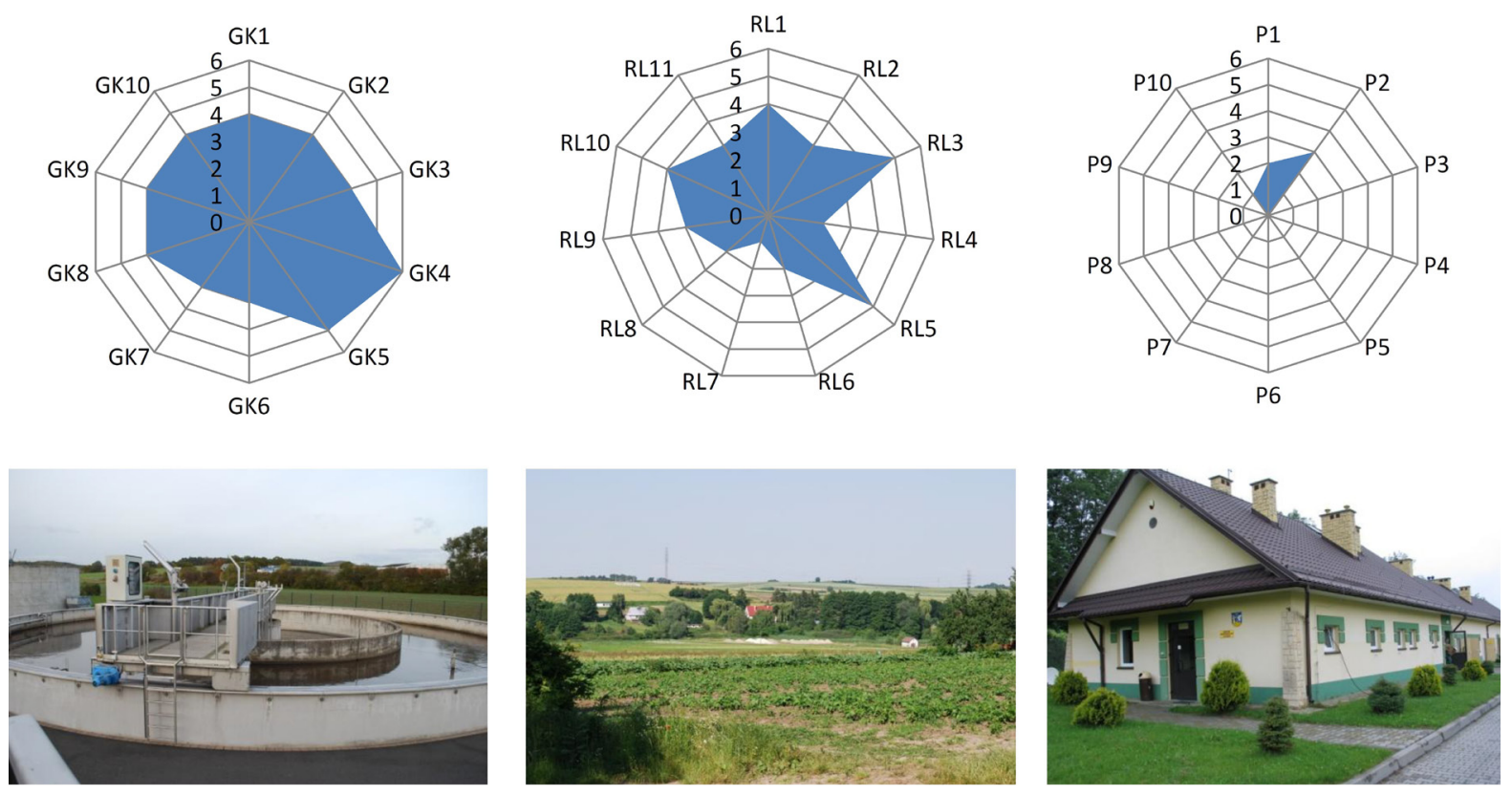

Figure 3. Assessment of pressure from municipal economy (GK), agriculture and forestry (RL) and industry (P) on water resources of catchment Korzkiewka

Table 3. Indices used for assessing pressure from municipal economy on water resources of catchment Korzkiewka

\begin{tabular}{|l|l|l|l|}
\hline \multicolumn{1}{|c|}{ Symbol } & \multicolumn{1}{c|}{ Indices name } & \multicolumn{1}{c|}{ Value } & \multicolumn{1}{c|}{ Degree of pressure } \\
\hline GK1 & Population density & 415 persons $\cdot \mathrm{km}^{-2}$ & high (4) \\
\hline GK2 & Water consumption for water supply network & $0.54 \mathrm{dm}^{3} \cdot \mathrm{s}^{-1} \cdot \mathrm{km}^{-2}$ & high (4) \\
\hline GK3 & Population using sewage network & $214 \mathrm{persons} \cdot \mathrm{km}^{-2}$ & high (4) \\
\hline GK4 & Sewage discharged through sewage network & $0.36 \mathrm{dm}^{3} \cdot \mathrm{s}^{-1} \cdot \mathrm{km}^{-2}$ & out of range (6) \\
\hline GK5 & Municipal waste collected & $107 \mathrm{Mg} \cdot \mathrm{km}^{-2} \cdot \mathrm{year}^{-1}$ & very high (5) \\
\hline GK6 & Municipal land in catchment area & $2.6 \%$ & average (3) \\
\hline GK7 & Proportion of people using sewage network & $52 \%$ & average (3) \\
\hline GK8 & Length of sewage network to length of water supply network & $1.00 \mathrm{~km} \cdot \mathrm{km}^{-1}$ & high (4) \\
\hline GK9 & Tourist accommodations provided & 177 persons $\cdot \mathrm{km}^{-2}$ & high (4) \\
\hline GK10 & Number of accommodated tourists to catchment population & $43 \%$ & high (4) \\
\hline
\end{tabular}

level. Sewage discharged by the sewage network constitutes $0.36 \mathrm{dm}^{3} \cdot \mathrm{s}^{-1} \cdot \mathrm{km}^{-2}$. Due to dispersed residential buildings, the part of the district with compact building has a sewage network. Sewage is discharged into the sewage system of the city of Krakow. The 9 household sewage treatment plants located in the district are utilized by 26 inhabitants. The non-sewered areas pose a threat of uncontrolled sewage discharge by households into the natural environment. The Korzkiewka stream revealed the status below good along its whole length, among others due to concentrations of ammonium nitrogen, which may indicate the unsettled sewage management in the catchment area. Increase in nitrite nitrogen concentrations and phosphate phosphorus concentration jumps were observed in the stream water (point 3 ) by the sewage treatment plant located next to the School Complex in Korzkiew, which might be caused by the treated sewage discharge. Collected municipal waste amounted to $107 \mathrm{Mg} \cdot \mathrm{km}^{-2}$.year ${ }^{-1}$ (very high level). $0,307 \mathrm{Mg}$ of municipal waste per capita per year in the district is the value approximate to the value of municipal waste collected in Poland per capita per year. Water resources in the catchment may be under a considerable pressure of tourist and leisure activities. The number of tourists is high due to an attractive location in the area of the Ojcow National Park Buffer zone. This is a good place for resting, with numerous walking and biking trails. The other tourist attractions are also a medieval castle in Korzkiew and "Botoja" horse stud. In 2011 the local tourist accommodation was provided for 5405 people, which gave 177 
persons per $\mathrm{km}^{2}$ (high level) (Table 3 ). The number of accommodated tourists reached 55346. The number of tourists was equal to $43 \%$ (high level) of the district population. Increased pollution of the Korzkiewka stream water noted from June to October may be connected with tourist activities in the catchment.

The land use and environmental conditions have a marked impact on surface water quality in the Korzkiewka stream catchment. The catchment area is used for farming because of good quality soils revealing a large thickness of the humus horizon and abundant in nutrients. Agriculture develops mainly in the upper part of the catchment in Smardzowice and Cianowice Duże villages in Skała district, but also at the settlement clusters in Brzozówka Korzkiewska. There are usually small holdings, which cultivate the land for their own needs. The analyzed region is well known for vegetable and fruit production.

The agricultural lands constitute $79 \%$ of the district area (high level), arable lands 52\% (high level) and orchards 18\% (high level) (Table 4). Vegetable and fruit production is well developed in the district. Intensive cultivation involves the application of plant protection chemicals and herbicides, which unfavourably affect the state of the natural environment. Phosphorus, potassium and nitrogen fertilizers are the cause of water pollution with biogens. Pollutants penetrate into water with surface runoffs, via drains and ditches, whereas their source may be located far from the contaminated place. Nitrate nitrogen exceeded the quality standards along the whole length of the studied stream and the water was classified to the status below good.

The upper part of the Korzkiewka stream catchment, where its source is situated, is an intensively used farmland. The highest concentration of nitrate nitrogen as compared to the other parts of the stream waters was registered in this part. The reason is a hydrogeological structure, which enables fast penetration of rainwater with pollutants from the surface to the groundwater reservoir. The waters in the Ojcow National Park area have permanently elevated concentrations of nitrates, which may be the result of the whole groundwater reservoir pollution [Wiśnios et al. 2015].

Forest lands (forests, lands covered with trees and bushes) and the areas under legal protection of the natural environment, positively affect the quality of ground and surface waters [PolichtLatawiec et al. 2014]. Therefore, low woodiness on the level of $10 \%$ (low level) influences the amount and the speed at which area pollutants penetrate into the waters. Small forest complexes occur in the Korzkiewka stream catchment, close to the watercourse (Figure 1). The whole catchment is situated in the protected areas in the Ojcow National Park buffer zone and the Dhubnia Landscape Park buffer zone. A small, isolated part of the Ojcow National Pak is located in the central part of the catchment.

Animal farming involves a problem of animal faeces storage: farmyard manure and liquid manure, but also keeping silages. Poultry was the dominant farm animal species in the catchment area. Sheep, cattle and pig breeding were, respectively on high, medium, very low and low level. A livestock unit was 20 per 100 hectares of arable lands (Table 4). In the vicinity of farms keeping farm animals, the studied stream revealed higher concentrations of potassium and chlorides, which may indicate improper storage and keeping liquid and solid animal faeces.

Mainly private commercial and service providing entities operate in the investigated area. There are no large industrial centres. Business activities in the construction sector, production and supply of electric energy, water and gas or industrial processing are slight. Concerning the entities involved in the production and supply of electricity, water and gas the activities are on a low (section D) and medium level (section F). Wastes generated by industry constituted 0.4 $\mathrm{Mg} \cdot \mathrm{km}^{-2} \cdot$ year $^{-1}$ (very low level) (Table 5).

No industrial wastes are stored in the catchment area. Water consumption for the needs of the national economy and industry is zero. No water is taken from either surface of ground waters for industrial purposes. Pollutants from industry may penetrate to the catchment area from the nearby Krakow city carried by air masses.

\section{CONCLUSIONS}

The following conclusions were formulated on the basis of the conducted investigations:

1. Analyses of physicochemical indices revealed that along the whole length of the Korzkiewka stream waters qualified for the below good status because of the exceeded values of EC and nitrate nitrogen concentrations. In the headwaters segment water is most polluted, as apart from the indices mentioned above, also con- 
Table 4. Indices used for assessing pressure from agriculture and forestry on water resources of catchment Korzkiewka

\begin{tabular}{|c|c|c|c|}
\hline Symbol & Indicator name & Value & Degree of pressure \\
\hline RL1 & Proportion of agricultural land in catchment area & $79 \%$ & high (4) \\
\hline RL2 & Proportion of arable land in catchment area & $52 \%$ & average (3) \\
\hline RL3 & Proportion of orchards in catchment area & $18 \%$ & very high (5) \\
\hline RL4 & Proportion of forests in catchment area & $10 \%$ & low (2) \\
\hline RL5 & Proportion of protected land in catchment area & $100 \%$ & very high (5) \\
\hline RL6 & Breeding & $20 \mathrm{LU} \cdot 100 \mathrm{ha}^{-1} \mathrm{AL}$ & low (2) \\
\hline RL7 & Cattle-breeding & 12 head $\cdot 100$ ha $^{-1} \mathrm{AL}$ & very low (1) \\
\hline RL8 & Pig-breeding & 34 head $\cdot 100$ ha $^{-1} \mathrm{AL}$ & low (2) \\
\hline RL9 & Sheep-breeding & 2 head $\cdot 100$ ha $^{-1} \mathrm{AL}$ & average (3) \\
\hline RL10 & Horse-breeding & 3 head $\cdot 100$ ha $^{-1} \mathrm{AL}$ & high (4) \\
\hline RL11 & Poultry-breeding & 453 head $\cdot 100$ ha $^{-1} \mathrm{AL}$ & average (3) \\
\hline
\end{tabular}

Table 5. Indices used for assessing pressure from industry on water resources of catchment Korzkiewka

\begin{tabular}{|l|l|l|l|}
\hline Symbol & \multicolumn{1}{|c|}{ Indices name } & \multicolumn{1}{c|}{ Value } & \multicolumn{1}{c|}{ Degree of pressure } \\
\hline P1 & Section D - Processing industry (commercial entities) & $0.19 \mathrm{units} \cdot \mathrm{km}^{-2}$ & low (2) \\
\hline P2 & $\begin{array}{l}\text { Section E - Electric power, gas and water production and supply } \\
\text { (commercial entities) }\end{array}$ & 0 units $\cdot \mathrm{km}^{-2}$ & lack (0) \\
\hline P3 & Section F - Construction (commercial entities) & $0.51 \mathrm{units} \cdot \mathrm{km}^{-2}$ & average (3) \\
\hline P4 & Water consumption for national economy & $0 \mathrm{dm}^{3} \cdot \mathrm{s}^{-1} \cdot \mathrm{km}^{-2}$ & lack (0) \\
\hline P5 & Water consumption for industry & $0 \mathrm{dm}^{3} \cdot \mathrm{s}^{-1} \cdot \mathrm{km}^{-2}$ & lack (0) \\
\hline P6 & Underground water uptake for industry & $0 \mathrm{dm}^{3} \cdot \mathrm{s}^{-1} \cdot \mathrm{km}^{-2}$ & lack (0) \\
\hline P7 & Surface water uptake for industry & $0 \mathrm{dm}^{3} \cdot \mathrm{s}^{-1} \cdot \mathrm{km}^{-2}$ & lack (0) \\
\hline P8 & Cooling water & $0 \mathrm{dm}^{3} \cdot \mathrm{s}^{-1} \cdot \mathrm{km}^{-2}$ & lack (0) \\
\hline P9 & Area of industrial landfill sites in district area & $0 \%$ & lack (0) \\
\hline P10 & Industrial wastes generated & $0.4 \mathrm{Mg} \cdot \mathrm{km}^{-2} \cdot \mathrm{year}$ & very low (1) \\
\hline
\end{tabular}

centrations of chlorides and magnesium did not meet the requirements for quality class II.

2. Changes of the values of water quality indices depended on the land use form. In the headwaters part the land was intensively farmed, which affected values of salinity and biogenic (mainly nitrate nitrogen) indices in the stream water. In the central reach of the stream the highest values of phosphate phosphorus and ammonium nitrogen were registered, which might have been connected with water discharge from a sewage treatment plant and intensified tourist movement in this area.

3. It was found that among 21 analyzed physicochemical indices, statistically significant differences occurred for 5: total dissolved solids, $\mathrm{SO}_{4}{ }^{2-}, \mathrm{Mg}^{2+}, \mathrm{K}^{+}$and water $\mathrm{pH}$. In the headwaters section, values of four salinity indices were significantly higher in relation to the other parts of the stream.

4. The assessment of anthropogenic factors affecting the catchment water resources, con- ducted on the basis of unitary and percent indices revealed, that the dominant category shaping physicochemical status of the Korzkiewka stream water is municipal economy. The intensity of impact of the factors from this category ranged from medium (3) to very high (5), and in case of sewage discharged through sewage network even to the outlier (6). Forestry and agriculture exerted a medium pressure, whereas the factors from the industry category had hardly any impact on the quality of water in the stream.

\section{REFERENCES}

1. Dąbrowska J., Moryl A., Kucharczak-Moryl E., Żmuda R., Lejcuś I. 2016. Content of nitrogen compounds in the waters of the Strzegomka River above the Dobromierz Reservoir. Acta. Sci. Pol., Formatio Circumiectus, 15(3), 57-69. (in Polish)

2. Directive 2000/60/EC of the European Parliament and of the Council establishing a framework for Community action in the field of water police. OJ 


\section{327, 21.12.2000.}

3. Húska D., Krupová K., Halaj P., Mandalová K. 2013. Ewaluation of surface water Žitava catchment under the aspect of anthropogenic impact. Acta Sci. Pol. Formatio Circumiectus, 12(3), 41-51.

4. Nachlik E. (ed). 2014. Identification and assessment of anthropogenic impacts on water resources to identify water bodies at risk of failing to meet environmental targets. Monograph 318, ser. Inż. Środ., PK Kraków. (in Polish)

5. Jóźwiakowski K., Marzec M., Obroślak R. 2006. Changes of surface water quality in the valley of Ciemiega River in 1999-2004. Roczniki Gleboznawcze, 57(3-4), 37-43. (in Polish)

6. Kanownik W., Kowalik T. 2010. Variability of water resources flowing away from small agricultural catchment. Polish J. of Environ. Stud. 19(1). 65-71.

7. Kanownik W., Kowalik T., Bogdał A., Ostrowski K. 2013. Quality categories of stream waters included in a small retention program. Pol. J. of Environ. Stud. 22(1). 159-165.

8. Kowalik T., Kanownik W., Bogdał A., Policht-Latawiec A. 2014. Effect of change of small upland catchment use on surface water quality course. Rocznik Ochrona Środowiska, 16(1), 223-238. (in Polish)

9. Marks-Bielska R. 2011. Chosen aspects of sustainable development in Poland with particular focus on agriculture. Management theory and studies for rural business and infrastructure development, 2(26), 160-168.

10. Mazur A. 2013. The effect of the surface wash on the water quality of the Źółkiewka River. Gaz, Woda i Technika Sanitarna, 2, 64-66. (in Polish)

11. Mioduszewski W. 2015. Protection of water quality in the lake situated on the agricultural area. Journal of Water and Land Development, 26(VII-IX), 65-71.

12. Policht-Latawiec A., Kanownik W. 2015. Hydrochemical conditions of the Łososina river water management in the area of Tymbark. Journal of Ecological Engineering, 16(5), 151-159.

13. Policht-Latawiec A., Kanownik W., Cieślik A. 2015. Hydrochemical conditions in water management of Korzkiewka stream. Technologia Wody, 6(44), 50-55. (in Polish)
14. Policht-Latawiec A., Kanownik W., Wójcik P. 2014. Quality and usable values of water of flysch stream with low anthropopressure. Infrastruktura $\mathrm{i}$ Ekologia Terenów Wiejskich, III/1. 917-929. (in Polish)

15. Environmental Impact Assessment. Update of the Environmental Protection Program for the Zielonka Commune for the years 2012-2015 with a perspective until 2019. Zielonki 2012. (in Polish)

16. Pytka A., Jóźwiakowski K., Marzec M., Gizińska M., Sosnowska B. 2013. Impact assessment of anthropogenic pollution on water quality of Bochotniczanka River. Infrastruktura i Ekologia Terenów Wiejskich, 3/II, 15-29. (in Polish)

17. Regulation of the Minister of the Environment dated 19 July 2016 on the forms and ways of monitoring uniform parts of surface and groundwaters. Journal of Laws 2016, item 1178. (in Polish) [Regulation ME 2016a]

18. Regulation of the Minister of the Environment dated 21 July 2016 on the method of classification of the state of uniform parts of surface waters and environmental quality standards for priority substances. Journal of Laws 2016, item 1187. (in Polish) [Regulation ME 2016b]

19. Smoroń S., Kowalczyk A. 2014. Identification and evaluation of anthropogenic factors posing potential threat to Szreniawa River waters. WodaŚrodowisko-Obszary Wiejskie, 14(3), 125-141. (in Polish)

20. Sojka M., Jaskuła J., Wicher-Dysarz J. 2016. Assessment of biogenic compounds elution from the Główna River catchment in the years 1996-2009. Rocznik Ochrona Środowiska, 18(1), 815-830. (in Polish)

21. Sojka M., Murat-Błażejewska S., Kanclerz J. 2008. Assessment of non-point anthropogenic pressures on water quality of Struga Dormowska stream. Acta Sci. Pol., Formatio Circumiectus, 7(2), 1527. (in Polish)

22. Stanisz A. 2007. A simple course in statistics using STATISTICA PL on examples from medicine. StatSoft Poland. Krakow, pp. 500. (in Polish)

23. Wiśnios M., Kanownik W., Bogdał A. 2015. Hydrochemistry of springs in the Ojcow National Park. Acta Sci. Pol., Formatio Circumiectus, 14 (3), 205-217. (in Polish) 